\title{
65 Years from Birth of Prof. Gheorghe S. Nadiu (1941-1998)
}

\author{
Ioan Dziţac, Loriana Andrei
}

\begin{abstract}
In 1967, Gheorghe S. Nadiu publishes in "Mathematical studies and researches", the article "On a method for the construction of Three - valued Łukasiewicz algebras" (Romania), cited in the book "Cylindric Algebras" by P. Monk, L. Henkin, A. Tarski. This article attracted the attention of Grigore C. Moisil, who offers him a scholarship, taking him out of production to make his doctorate at the Mathematic Institute of the Romanian Academy. He publishes more than 50 scientific papers in Theory of Algorithms, Logics of mathematics and Theory of Categories fields.

"Gheorghe S. Nadiu, by introducing the notion of quantified filter in a boolean monadic algebra, showed how one can obtain a trivalent Łukasiewicz algebra; also, he obtained an algebraic characterization of a completitude theorem from the intuitionist logic of Kripke.” (G. St. Andonie, Science History in Romania, Academic Publishing House, SRR, 1981).
\end{abstract}

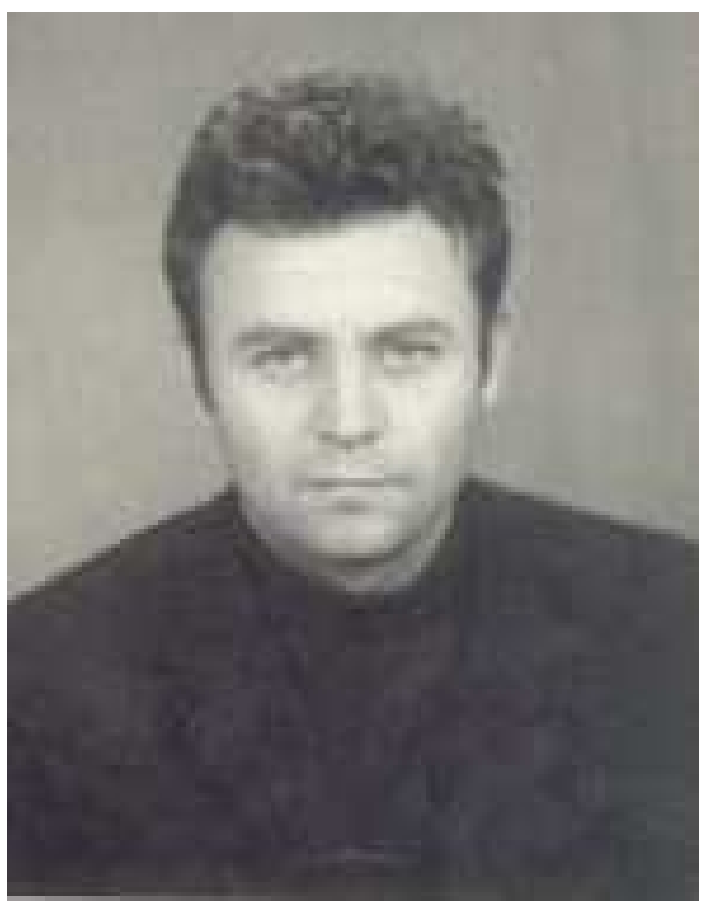

PhD Student Gheorghe Nadiu (1970) at Mathematical Institute of the Romanian Academy

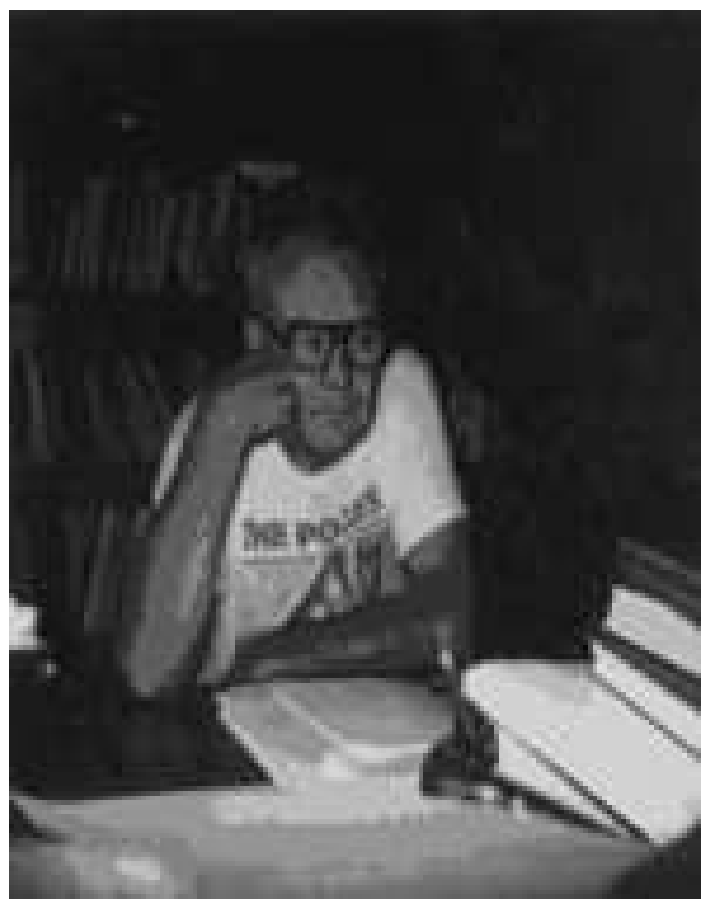

Prof. univ. dr. Gheorghe Nadiu (1997)

Director of Mathematics Department University of Oradea (1990-1994, 1996-1998)

\section{Biographical dates}

Name and surname: Nadiu Gheorghe

Date and place of birth: 1941, September, 12, Comlăuş-Sântana, Arad County, Romania

Date and place of dead: 1998, November 7, Oradea, Bihor County, Romania

Wife: Nadiu Doina Elena

Children: 1. Loriana; 2. Adina

Fields of Scientific Research: Theory of Algorithms, Mathematical Logic, Category Theory 
1956-1959: Pupil at "Moise Nicoară" High School, Arad, Arad County, Romania

1959-1964: Student at Faculty of Mathematics and Physics, "Babes-Bolyai" University of Cluj

1964-1969: Assistant Professor at Pedagogical Institute of Oradea, Bihor County, Romania

1969-1972: PhD student at Mathematical Institute of the Romanian Academy (supervisor prof. Grigore C. Moisil)

1972: He obtain PhD in Mathematics with the PhD Thesis: "Cercetări asupra logicilor necryssipiene" / "Research about Necryssipiene Logics" (supervisor Grigore C. Moisil)

1973-1978: Lecturer at Pedagogical Institute of Oradea

1980-1990: Associate Professor at Pedagogical Institute of Oradea

1990- 1998: Professor at University of Oradea.

\section{Didactical and managerial activity}

After graduating the Faculty of Mathematics-Physics at the "Babeş-Bolyai" University of Cluj, in 1964, Gheorghe S. Nadiu becomes teaching assistant at the Pedagogic Institute from Oradea, job in which he functions until 1969, holding seminars of Theory of Probabilities, Differential equations, Theoretical mechanics and in the University Year 1968/1969 he teaches the course "Fundamentals of Mathematics".

During 1969-1972 he is taken out of Education after obtaining a scholarship for executing the doctorate in mathematics under the scientific leading of professor Grigore C. , Moisil, at the Mathematic Institute of the Romanian Academy.

In 1972, after obtaining the title of Doctor in Mathematics, (Mathematical Logics) he comes back to his old workplace where he gets, through contest, a job as lecturer for the disciplines "Fundamentals of Mathematics" and "Mathematical Logics" which he teaches until 1978.

In 1978 he becomes titular of the courses "Superior Mathematics" and "Computer programming", and in 1980 he occupies by contest the job as readership, on which he functions until 1990 when he obtains, by contest, the didactic title of University professor.

In 1990 the Institute from Oradea changes into University, and professor Nadiu becomes headmaster of the Mathematics Department of the University of Oradea, which he founds starting from a department with 2 personnel and develops until obtaining a department of over 30 personnel who operates in the whole University, and which he leads between 1990-1994 and 1996-1998.

Between 1990-1998 he teaches the courses "Mathematical Logics" and "Functional Analysis" at the Science Faculty of the University of Oradea, at the specializations mathematics-informatics and mathematics-physics.

He dies prematurely, at the early age of 57, because of cardio-respiratory death, still in full didactical working potential and creative scientific activity.

\section{Scientific activity}

In his first published scientific work [1], written as student, in collaboration with prof. Petre Brdeanu from Cluj, he presents an optimal moving regime of the ballistic missile, under the form of periodical functioning of exponential type of the engine, with help of the maximum principle of Pontriaghin.

The main directions of scientific research of Gh. Nadiu were directed to the Theory of Algorithms, Logics of mathematics, and Theory of Categories.

In the works [2,4] and [5], from the field of algorithms theory, first, there is given a double recursion theorem, in sense of Asser' recursion theorem, and then a localization procedure of algorithms of Nogornâi type through the medium of Cernevski type, introduced by the author, as well as the construction of a universal Turing machine for the normal class algorithms of A. A. Markov. 
In the field of mathematical logic Nadiu introduces in [3] an algebraic method of construction of trivalent Łukasiewicz algebras, starting from the monadic boolean algebras, by means of quantified filters introduced by him. This result is quoted in the treaty "Cilindric Algebras" by Henkin, Monk and Tarski [8]. Afterwards, the results are taken over in some researches of Luiz Monteiro from the University Bahia Blanca from Buenos Aires, Argentina.

Then, in [7], [9] and [10], there is given an interpolation theorem of Craig type for the strict positive logic and also a series of results of relative categorical order at the category of models for elementary logic of Moisil.

In the doctoral dissertation "Research on necryssipic logics" [11] elaborated under the scientific leadership of Grigore C. Moisil, sustained in 1972, G.S. Nadiu introduces the notion of "abstract calculation of superior order" as general developing frame of logic systems and gives then extensions of Moisil's modal logics and of logic of Nelson's and A. A. Markov's false constructible, the results are being found in [16].

In the same [11], Gh. S. Nadiu treated also S. Kripke theorem of completitude for Heyting intuitionist logic, from point of view of topological models. After this, he studies the pseudo - boolean pre - fascicle introduced by him through analogy with the Kripke models, for which he gives a series of categorical properties.

The results obtained by Gh. Nadiu in his doctoral dissertation [11] and published in "Logique Automatique - Informatique" (1971) are in concordance with the results contained in the work of David P. Ellerman [12], which treats a particular case of pseudo - boolean pre - fascicle with values in the category of relational structures.

The studies of formal systems, in categorical sense, lead Gh. Nadiu to results related by the closed Cartesian categories [14] and to the obtaining of an exponentation theorem Birkoff type, in such categories as well as also to the development of the skolem pre - fascicle theory, introduced by him in [18, $20,21,22]$ which led him to fiber categories.

The algebraic study of the polyvalence in sense of Moisil's ideas led him to the introduction of notions of lattice under - reziduate Skolem [23].

In the ulterior works he developed the correspondence category and of general correspondence, ulterior applied at the monad theory.

Also, in the sense of Fröllich formal group, he gave a characterization of formal commutative Moufang curls [15], introduced by S. Basarab.

After 1980 his researches have been oriented to the study of the influence of mathematic logic in various branches of mathematics: functional analysis, algebra, auto-reglation problems in the theory of abstract automatics, model theory for theories with more variable sorts with application at the normative spaces theory.

\section{References}

[1] P. Brădeanu, Gh. S. Nadiu, Asupra unui regim optim de mişcare a rachetelor balistice, An. Univ. din Timişoara, vol. III, 1965.

[2] Gh. S. Nadiu, Asupra unei teoreme de recursie a algoritmilor normali, Studii şi cercetări matematice (Mathematical Reports), Tom. 18, 1966/7, pp. 1071.

[3] Gh. S. Nadiu, On a method for the construction of three-valued Łukasiewicz algebras (Romanian), Studii Cerc. Mat., 19, 1967, 1063-1070.

[4] I. Maruşciac, Gh. S. Nadiu, O interpretare a algoritmilor, schemă-graf în legătură cu maşinile Turing şi algoritmi de tip Cernevski, Studii şi cercetări matematice, Tom. 20, 1968/7. 
[5] Gh. S. Nadiu, The interpolation theorem in strict positive logic, Bull. Math. Soc. Sci. Math. Roum., Tom. 13, 1968/2.

[6] Gh. S. Nadiu, O maşină Turing universală pentru clasa algoritmilor normali, Studii şi cercetări matematice, Tom. 21, 1969/1.

[7] Gh. S. Nadiu, Sur la logique de Heyting, in "Logique-Informatique-Automatique", Ed. of Romanian Academy, Bucureşti, 1971.

[8] L. Henkin, J.D. Monk, A. Tarski, Cylindric Algebras, North-Holland, Amsterdam 1971.

[9] Gh. S. Nadiu, Sur la logique de Heyting, Abstract of IV Congress of logic, Bucharest, 1971.

[10] Gh. S. Nadiu, Elementary logic and models, Bull. Math. d Soc. Sci. Math. Roum., Tom. 15, 1971/1.

[11] Gh. S. Nadiu, Cercetări asupra logicilor necryssipiene/Research about Necryssipiene Logics, 1972 (PhD Thesis, supervisor Grigore C. Moisil).

[12] David P. Ellerman, Sheaves of Structures and Generalized Ultraproducts, Annals of Mathematical Logic, 7 (Dec. 1974), 163-195.

[13] Gh. S. Nadiu, An abstract calculi of superior order, Proc. of IV Congress of logic,, London-Ontario, Canada, 1975.

[14] Gh. S. Nadiu, O teoremă de exponenţiere în categorii cateziene, Lucr. Şt., Institul Ped. Oradea, 1977.

[15] Gh. S. Nadiu, Asupra buclelor Moufang formele comutative/Note sur les boucles Moufang formelles commutatives (Romanian), Stud. Cercet. Mat. 32, pp. 193-207, 1980.

[16] Gh. S. Nadiu, Notă asupra spaţiilor metrice constructive, Studii şi cercetări matematice, 1980.

[17] Gh. S. Nadiu, Non-Clasical Logic of Superior Order, Resegna internationale di logica, Bologna, Bull.Math., 1981.

[18] Gh. S. Nadiu, Considerations sur les categories cartesienes fermes, bull. math.

[19] G. St. Andonie, History of sciences in Romania. Mathematics, mechanics, astronomy, (Istoria Ştiinţelor în România. Matematica, mecanica, astronomie)(Romanian), Bucuresti: Ed. Acad. R.S.R.,1981, pp.123.

[20] Gh. S. Nadiu, Category of correspondence and extensions, Jounal of pure and appl. Algebra.

[21] Gh. S. Nadiu, On Boolean formal algebras, Bull. Math. d Soc. Sci. Math. Roum., 1978.

[22] Gh. S. Nadiu, Prefascicule peste latici Skolem (I), Lucrări Şt. ale Inst. de înv. sup. Oradea, 1978, ser. A, pp. 37-63.

[23] Gh. S. Nadiu, Asupra laticilor Skolem, Lucrări Şt. ale Inst. de înv. sup. Oradea, pp. 65-69, 1978.

[24] Nadiu, Gh.S., Considerations in category of Skolem lattices, (Romanian. English summary), Bul. Stiint. Inst. Politeh. Cluj-Napoca, Ser. Electroteh. Energ. Inf. 25, 29-36 1982.

[25] Gh. S. Nadiu, Logici cu mai multe sorturi de variabile şi spaţii vectoriale, în vol. Lucrările celui de al III-lea Simpozion naţional de analiză funcţională, Craiova, 6-7 nov. 1981. 
[26] Gh. S. Nadiu, T Pop, Automate-tehnologii şi decizii, în vol. "Cibernetică aplicată”, Bucureşti, Ed. Acad. R.S.R., 1983.

[27] Gh. S. Nadiu, Aspecte booleene în categoria spaţiilor vectoriale normate, în vol. Lucrările celui de al IV-lea Simpozion naţional de analiză funcţională, Craiova 6-7 nov. 1983.

[28] Gh. S. Nadiu, Prefascicule peste latici Skolem (II), Lucrăi Şt. ale Inst. de înv. sup. Oradea, seria A, 1978.

[29] Gh. S. Nadiu, Asupra logicii modale generale a lui Moisil, Lucrări Şt. ale Inst. de înv. sup. Oradea, seria A, 1978.

[30] Gh. S. Nadiu, Asupra ordonărilor Rudin-Kreisler în clasa ultrafiltrelor, Lucrări Şt. ale Inst. de înv. sup. Oradea, seria A, 1978.

[31] Gh. S. Nadiu, Contribuţii la teoria relaţiilor (I), Lucrări Şt. ale Inst. de înv. sup. Oradea, seria A, 1980.

[32] Gh. S. Nadiu, Contribu ctii la teoria relaţiilor (II). Corespondenţe via toposuri., Lucrări Ştiinţifice, Oradea, seria A, 1980.

[33] Gh. S. Nadiu, O clasă specială de L-endometrici probabiliste, Lucrări Ştiinţifice, Oradea, seria A, 1980.

[34] Gh. S. Nadiu, Gh. Niculae, Funcţii parţiale injective şi filtre de compunere, Lucrări Ştiinţifice, Oradea, seria A, 1980.

[35] Gh. S. Nadiu, Notă asupra relaţiilor de secvenţă, Lucrări Ştiinţifice, Oradea, seria A, 1979.

[36] Gh. S. Nadiu, Gh. Niculae, Asupra categoriei-algebrelor, Lucrări Ştiinţifice, Oradea, seria A, 19811982.

[37] Gh. S. Nadiu, Notă asupra filtrelor într-o algebră Łukasievich 0-valentă, Lucrări Şt., Oradea, seria A, 1981-1982.

[38] Gh. S. Nadiu, Contribuţii la teoria relaţiilor (III). Interpretări sintactice, Lucrări Şt., Oradea, seria A, 1981-1982.

[39] Gh. S. Nadiu, Dinamica deciziilor, Rezumat vol. Celui de al IV-lea Simpozion naţional de cibernetică, 1986.

[40] Gh. S. Nadiu, Asupra noțiunii de topologie, Simpozion naţional de topologie, Cluj Napoca, 1986.

[41] Gh. S. Nadiu, Produse fibrate în categoria automatelor, Comunicare la Conferinţa naţională de algebră, Timişoara, 1986.

[42] Nadiu, Gh. S., On topologies and overtopologies (English), Prepr., "Babes-Bolyai" Univ., Fac. Math. Phys., Res. Semin. 1988, No.2, pp. 121-126 (1988).

[43] Gh. S. Nadiu, Loriana Popa, Asupra teoriei omotopiei, Analele Univ. Oradea, III, pp. 12 - 19, 1993.

[44] Gh. S. Nadiu, Notă asupra spaţiilor liniar normate, Analele Univ. Oradea, I, pp. 91 - 94, 1991.

[45] Gh. S. Nadiu, Consideraţii algebrice relaţii la cat. sp. metrice., Analele Univ. Oradea, II, pp. 99 106, 1992. 
[46] Gh. S. Nadiu, Dinamici. Aspecte categoriale, Analele Univ. Oradea, III, pp. 1 - 12, 1993.

[47] Gh. S. Nadiu, Consideraţii asupra categoriilor carteziene, Lucrărrile CAIM 1996, pp. 201 - 207.

[48] A. Georgescu, C.L. Bichir, G.V. Cîrlig, Matematicieni români de pretutindeni, ED. The Flower Power, pp. 135, 2004.

[49] G. Georgescu, A. Iorgulescu, S. Rudeanu, Grigore C. Moisil (1906 - 1973) and his School in Algebraic Logic, Int. J. of Computers, Communications and Control, IJCCC Vol. I (2006), No.1, 81-89.

Ioan Dziţac

Agora University

8 Piata Tineretului 410526 ORADEA

ROMANIA

idzitac@univagora.ro

Loriana Andrei

University of Oradea

3-5 Universitatii St. 410087

ROMANIA 